\title{
Analysis of Different Fractions of Swertia Chirata Against Gram Positive and Gram Negative Bacteria
}

\author{
Lwin Lwin Nyein ${ }^{1, *}$, Isma Syahril B Ismail ${ }^{2}$ and Nik Aiman Afiq Bin Nik Ab Rahman ${ }^{3}$ \\ ${ }^{1}$ Faculty of Medicine, University Teknologi MARA, Malaysia \\ ${ }^{2}$ Institute of Medical Molecular Biotechnology, Malaysia \\ ${ }^{3}$ Faculty of Applied Sciences, University Teknologi MARA, Kulua Pihah, Malaysia
}

\begin{abstract}
Complementary and alternative medicine (CAM) is becoming increasingly popular and experienced a high growth all over the world. A medicinal plant, Swertia chirata, has been widely use as herbal medicine in Asian countries and some parts of the world. The aim of this study was to evaluate the antibacterial property of Swertia chirata. Plants were extracted using ethanol. Disc diffusion technique was used to determine antimicrobial activity. Crude extraction of whole plant showed significant antimicrobial activities against some gram positive and gram negative bacteria. Test materials at a concentration of $100 \mu \mathrm{g}$ disc $^{-1}$ were used to evaluate the antimicrobial activity and $30 \mu \mathrm{g}$ disc ${ }^{-1}$ concentration of Chloramphenicol was used as positive control. Zone of inhibition against Staphylococcus aureus, Bacillus cereus, Escherichia coli and Salmonella arizonae were $10 \mathrm{~mm}, 6 \mathrm{~mm}, 9 \mathrm{~mm}$ and $7 \mathrm{~mm}$ respectively. Minimum Inhibitory Concentration of the crude extract was determined by serial dilution technique which showed $128 \mu \mathrm{g} / \mathrm{ml}, 64 \mu \mathrm{g} / \mathrm{ml}, 128$ $\mu \mathrm{g} / \mathrm{ml}$ and $128 \mu \mathrm{g} / \mathrm{ml}$ respectively. Although the results obtained revealed inhibition against some gram positive and gram negative bacteria, a further study need to be carried out to detect the active compounds of this highly potent plant. Moreover, problems of drug resistance leading to recurrent infections highlight a need to search for new compounds for treatment of microbial infections. Hence, Swertia chirata which possesses antimicrobial activity, hope will complement if not replace a standard antimicrobial drug that will be of benefits to the health of the mankind.
\end{abstract}

Keywords: Swertia chirata, antibacterial, Complementary \& Alternative Medicine (CAM).

\section{INTRODUCTION}

Traditional systems of medicine are fast emerging as an alternative to modern medical and health science. In recent years the emphasis on herbal plants as a source for drug discovery and development has been realized globally [1]. The concept of scientific validation of the basis of traditional uses of herbal medicines has given birth to a new concept of reverse pharmacology, and interactions between traditional and modern systems of medicine are being increasingly encouraged. Recent Trends in Herbal Drug Research and Therapy showcases some of these crucial and emerging issues relating to herbal drugs [1]. The use of higher plants and preparations made from them to treat infections is an old-age practice in a large part of the world population, especially in developing countries, where there is dependence on traditional medicine for variety of diseases $[2,3]$. The economic crisis, high cost of industrialized medicines, inefficient public access to medicinal and pharmaceutical care, in addition to the side effects caused by synthetic drugs are of some of the factors contributing to the central role of medicinal plants in health care $[3,4]$. Hence, in this study different fraction of Swertia chirata, leaves and stems were studied for its antimicrobial property.

*Address correspondence to this author at the Faculty of Medicine, University Teknologi MARA, Malaysia; Tel: (+603)-6126 7652:

Fax: (+603)-6126 5224; E-mail: 1lnyein674@salam.uitm.edu.my
Biological Name: Swertia chirata, Family- Gentianaceae Indian Name: Chirayata, is a robust annual herb which grows up to about 1.5 meters in height. It has leaves in opposite pair about $10 \mathrm{cms}$ long, without stalks, pointed at the tip. The plant has numerous flowers, pale green in colour, tinged with purple, with long white or pink hairs and minute sharp pointed fruits. The whole plant, collected in its flowering stage and dried, constitutes the drug. It is found in the Himalayan ranges of India from Kashmir to Bhutan at an altitude of 1,200-3,000 m. It is also found in the Khasi Hills of Meghalaya at an altitude of 1,200-1,500 m. [5, 6]. It has long been used by the ayurvedic physicians as a bitter tonic. The plant contains a bitter glycoside chiratin, which yields on hydrolysis, two bitter principle, ophelic acid and chiratin. The latter is soluble in water. The ophelic acid is a brown hydroscopic substance which is soluble in water and alcohol. It also contains resin, tannin and 4 to 8 per cent of ash [5]. Chirata is an effective drug for reducing fever [7]. It has been widely use as herbal medicine in Asian countries particularly in India, Nepal, Myanmar, Arab and some parts of the European countries. Reported studies showed extracts of this plant has attributable properties as hypoglycemic, antipyretic [8], anti-inflammatory [9], antibacterial [10], antiviral [11], antimalarial, antihepatotoxic [5] and wound healing activity [12]. Moreover, it was also announced in Annual Professional Conference of Diabetes UK, 2009, proven to have an anti-diabetic effect [13]. In this study, 
Table 1. Antibacterial Activity of the Crude Extract of $S$. chirata Leaf

\begin{tabular}{|c|c|c|c|c|c|}
\hline Bacteria & $\mathbf{1 0 0 \%}$ & $\mathbf{7 5 \%}$ & $\mathbf{5 0 \%}$ & $\begin{array}{c}\text { Standard } \\
\mathbf{2 5 \%} \\
\text { Chloramphenicol Disc } \\
\mathbf{( 3 0 \mu g} \mathbf{d i s c}\end{array}$ \\
\hline \hline Percentage & 10 & 6 & - & - & 33 \\
\hline Staphylococcus aureus & 6 & - & - & - & 33 \\
\hline Bacillus cereus & 9 & 4 & - & - & 34 \\
\hline Escherichia coli & 7 & - & - & 33 \\
\hline Salmonella arizonae & & & & - \\
\hline
\end{tabular}

Table 2. Antibacterial Activity of the Crude Extract of $S$. chirata Stem

\begin{tabular}{|c|c|c|c|c|c|}
\hline Bacteria & $100 \%$ & $75 \%$ & $50 \%$ & $25 \%$ & $\begin{array}{c}\text { Standard } \\
\text { Chloremphenicol Disc } \\
\left(30 \mu \text { disc }^{-1}\right)\end{array}$ \\
\hline Staphylococcus aureus & 9 & 7 & - & - & 33 \\
\hline Bacillus cereus & 6 & - & - & - & 33 \\
\hline Escherichia coli & 9 & 4 & - & - & 34 \\
\hline Salmonella arizonae & 7 & - & - & - & 33 \\
\hline
\end{tabular}

Values indicate zone of inhibition (diameter in $\mathrm{mm}$ )

ethanolic extract of different fraction of Swertia chirata was evaluated to assess its antimicrobial property.

\section{MATERIAL AND METHODS}

Collection of plants: Dried plants of $S$. chirata were obtained from registered traditional herbal medicine center, Myanmar. Locally known as Seykhagyi, identification and confirmation was performed by licensed traditional herbal medicine expert.

Preparation of plant materials: Plants were separated into stem and leaves and cut into smaller pieces and placed in an autoclave at $40^{\circ} \mathrm{C} 24$ hours for further drying. Then it was weighed about $100 \mathrm{~g}$ for each stem and leaves and ground into coarse powder with grinding machine at the Institute of Medical Molecular Biotechnology, Sungai Buloh, Malaysia.

Extraction, evaporation and isolation of compounds: $100 \mathrm{~g}$ of plant sample were taken to dissolved with $80 \%$ ethanol in a $500 \mathrm{ml}$ conical flask and placed on a shaker for 7 days. It was decanted and filtered using fresh cotton wool. This procedure was repeated 3 times to the same filtrate to achieve as much active compounds as possible. Thus, total of $1500 \mathrm{ml}$ of filtrates was lastly obtained in a beaker. The solvent was then placed in rotatory evaporator until semisolid gummy mass was obtained. It was then preserved at $4^{0} \mathrm{C}$ until further analysis.

Crude extract of leaf and stem powder of $S$. chirata were then dissolved in $80 \%$ ethanol and ready to be tested with different microbial agents.

Tested microbial agents: Staphylococcus aureus and Bacillus cereus for gram positive bacteria, Escherichia coli and Salmonella Arizonae for gram negative bacteria were used as an experimental microorganisms isolated as pure culture from Center for Pathology \& Diagnostic Research
Laboratories (CPDRL), Universiti Teknologi MARA, Sungai Buloh, Malaysia.

Antimicrobial study: Disc diffusion method was performed according to Clinical and Laboratory Standards Institute guidelines [14] and Minimal Inhibitory Concentration (MIC) was carried out using the reference broth microdilution method as described by the National Committee for Clinical Laboratory Standards. Standard Chloramphenicol disc $\left(30 \mu \mathrm{g} \operatorname{disc}^{-1}\right)$ was use as a positive control. Test materials impregnated with respective solvents (different strength $100 \%, 75 \%, 50 \% \& 25 \%$ ) were soaked into $100 \mu \mathrm{g} \mathrm{disc}{ }^{-1}$ (Whattman filter paper disc) and antimicrobial potency was measured.

\section{RESULTS AND DISCUSSION}

The study revealed that different fraction of both leaves and stems of $S$. chirata showed antimicrobial property against some gram positive and gram negative microorganisms. Results were summarized in tables and figures. Table 1 showed antibacterial activity of the crude extract of $S$. chirata leaf and Table 2 showed antibacterial activity of the crude extract of $S$. chirata stem. Fig. (1) and Fig. (2) showed antibacterial activity of $S$. charata stem and leaves against $S$. aureus, B. cereus, E. coli, S. arizonae at different concentrations of $100 \%, 75 \%, 50 \%$ and $25 \%$ respectively. Table 3 showed the MIC $(\mu \mathrm{g} / \mathrm{ml})$ values of ethonolic extract of $S$. chirata.

Antibacterial property of ethanolic crude extract of both $S$. chirata leaves and stem showed both possessed inhibition against test organisms. For gram positive bacteria, zone of inhibition for $S$. aureus was $10 \mathrm{~mm}$ and $9 \mathrm{~mm}$ whereas for $B$. cereus $6 \mathrm{~mm}$ and $6 \mathrm{~mm}$ respectively. For gram negative bacteria, E.coli showed inhibition zone of $9 \mathrm{~mm}$ and $9 \mathrm{~mm}$ and $S$. Arizonae showed $7 \mathrm{~mm}$ and $7 \mathrm{~mm}$ respectively for full strength. In concentration of $75 \%$, only $S$. aureus and E.coli 

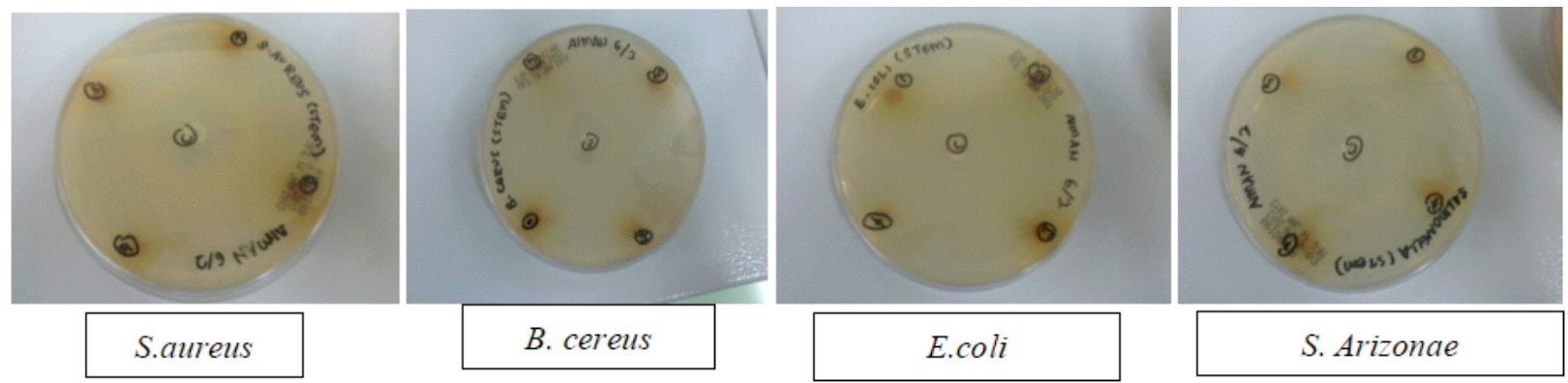

Fig. (1). Antibacterial activity of S. charata stem against S. aureus, B. cereus, E. coli, S. arizonae at different concentrations of $100 \%$, $75 \%$, $50 \% \& 25 \%$. Standard Chloramphenicol disc $\left(30 \mu \mathrm{g} \mathrm{disc}^{-1}\right)$ placed at the center of the plate.
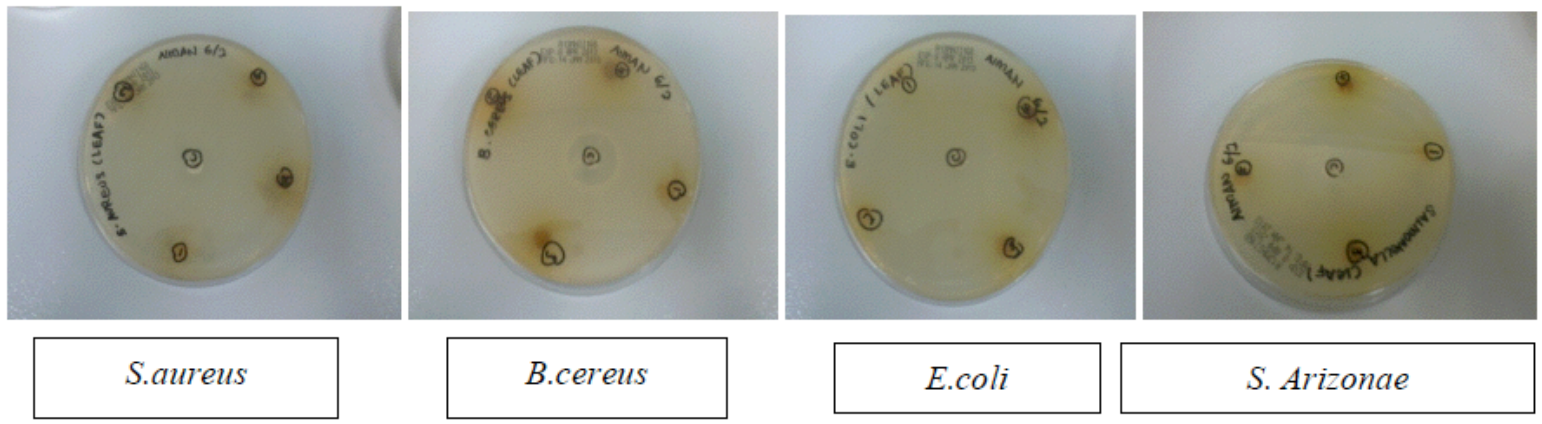

Fig (2). Antibacterial activity of $S$. charata leaves against S. aureus, B. cereus, E. coli, S. Arizonae at different concentrations of $100 \%$, $75 \%$, $50 \% \& 25 \%$. Standard Chloramphenicol disc $\left(30 \mu \mathrm{g} \mathrm{disc}^{-1}\right)$ placed at the center of the plate.

showed inhibition zone a little less than full strength, others revealed no significant inhibition. The results support previous studies $[15,3]$ and showed that antimicrobial activity was best at full concentration.

\section{MINIMUM INHIBITORY CONCENTRATION (MIC) OF THE TEST SAMPLE}

Minimum Inhibitory Concentration (MIC) of ethanolic crude extract mixture (stem and leaves) was determined by serial dilution technique shown in Table $\mathbf{3}$.

Table 3. Minimum Inhibitory Concentration $(\mu \mathrm{g} / \mathrm{ml})$ Values of ethonolic extract of $S$. chirata

\begin{tabular}{|c|c|}
\hline Tested Bacteria Strain & MIC $(\boldsymbol{\mu g} / \mathbf{m l})$ \\
\hline \hline Gram positive & $128 \mu \mathrm{g} / \mathrm{ml}$ \\
Staphylococcus aureus & $64 \mu \mathrm{g} / \mathrm{ml}$ \\
Bacillus cereus & \\
\hline Gram negative & $128 \mu \mathrm{g} / \mathrm{ml}$ \\
Escherichia coli & $128 \mu \mathrm{g} / \mathrm{ml}$ \\
\hline Salmonella Arizonae & \\
\hline
\end{tabular}

Minimal inhibition Concentration revealed $128 \mu \mathrm{g} / \mathrm{ml}$ for S. aureus, $64 \mu \mathrm{g} / \mathrm{ml}$ B. cereus, $128 \mu \mathrm{g} / \mathrm{ml}$ for both E.coli and $S$. Arizonae respectively as shown in Table $\mathbf{3}$.

\section{CONCLUSION}

The ethanolic extract of the medicinal plant $S$. chirata both stem and leaves demonstrate appreciable antibacterial property. Although the results obtained revealed inhibition against some gram positive \& gram negative bacteria, a further study need to be carried out to detect the active compounds of this highly potent plant. Moreover, problems of drug resistance leading to recurrent infections highlight a need to search for new compounds for treatment of microbial infections. Hence, S. chirata which possesses antimicrobial activity will complement if not replace a standard antimicrobial drug that will partly solved the problem of emergence of drug resistance. Further work will be continued for the identification of the isolated pure compound as well as its biological activity against microorganisms.

\section{CONFLICT OF INTEREST}

The authors confirm that this article content has no conflicts of interest.

\section{ACKNOWLEDGEMENTS}

This research was supported by RMI, UiTM, Malaysia, project code 600-RMI/ST/DANA 5/3/Dst (359/2011). Special thanks to Prof Dr Nor Hadiani Ismail for her support and encouragements.

\section{REFERENCES}

[1] Arunabha, R.; Kavita, G. Recent Advances in Herbal Drug Research and Therapy. I.K. International, 2010, pp. 20-34.

[2] Ahmad, I.; Mehamood, Z.; Mohammad, F.Screening of some Indian medicinal plants for their antimicrobial properties. J. Ethnopharmacol., 1998, 62, 183-193.

[3] Alam, K. D.; Ali, M. S.; Parvin, S.; Mahjabeen, S.; Akbar, M. A.; Ahamed, R. In vitro Antimicrobial activities of different fractions of Swertia chirata ethanolic extract. Pak. J. Biol Sci., 2009, 12(19), 1334-1337.

[4] Johann, S.; Pizzolatti, M. G.; Donnici, C. L.; de-Resende, M. A.; Paulo, S. Antifungal properties of plants used in Brazilian traditional medicine against clinically relevant fungal pathogens. Braz. J. Microbiol., 2007, 38, 11-14. 
[5] Joshi, P.; Dhawan, V. Swertia chirayita - an overview. Curr. Sci., 2005, 89(4), 635-640.

[6] Khalid, A.; Amir, W.; Malik, S.; Uzair-Ur-Rehman, Sonia, K. A.; Seth, Mhd, Hassham, H.;B. Alternative Medicine News. Health News Posted on March 12, 2011.

[7] Sampath, K. P.; Kumar, Debjit, Bhowmik, Chiranjib, Biswajit, Margret Chandira 2010.

[8] Bhargava, S.; Rao, P. R.; Bhargava, P.; Shuklas S. Antipyretic potential of Swertia chirata Buch Ham. Root extract. Sci. Pharm., 2009, 77, 617-623.

[9] Banerjee, S.; Kumar Sur, T.; Mandal, S.; Das, P. C.; Sikdar, S. Assessment of the anti-inflammatory effects of Swertia chirata in acute and chronic experimental models in male albino rats. Ind. $J$. Pharmacol., 2000, 32, 21-24.

[10] Ali, M. S.; Parvin, S.; Akbar, M. A.; Alam, K. D.; Mahjabeen, S.; Ahmed, R. Swertia chirata: A traditional herb and its medicinal uses. J. Chem. Pharm., 2009, 2(1), 262-266.
[11] Verma, H.; Patil, P. R.; Kolhapure, R. M.; Gopalkrishna, V. Antiviral activity of the Indian medicinal plant extract, Swertia Chirata against herpes simplex viruses. Ind. J. Med. Microbiol., 2008, 26(4), 322-326.

[12] Rafatullah, S.; Tariq, M.; Mossa, J. S.; Al-Yahya, M.;A.; Al-Said, M.S.; Ageel. Protective effect of Swertia chirata against indomethacin and other ulcerogenic agent-induced gastric ulcers. Clin. Res., 1993, XIX(2), 69-73.

[13] Health News. Alternative Medicine News. www.foxnews.com/health/index.html [Accessed March 12, 2011].

[14] CLSI: Clinical and Laboratory Standards Institute guidelines, CLSI - Antimicrobial Susceptibility Testing Standards: USA.

[15] Jesmin, M. S.; Molla, M.D.T.H.; Alam, M. T.; Shaki, Ahmad, M.R. Investigation on antimicrobial activities of the plant Swertia chirata. Ham. J. Life Earth Sci., 2007, 2(2), 31-34.

Received: May 29, 2013

(C) Nyein et al.; Licensee Bentham Open.

This is an open access article licensed under the terms of the Creative Commons Attribution Non-Commercial License (http://creativecommons.org/licenses/by$\mathrm{nc} / 3.0 /$ ), which permits unrestricted, non-commercial use, distribution and reproduction in any medium, provided the work is properly cited. 